\title{
Gas turbines - technological development and potential use in CAES systems
}

\author{
This article briefly describes Compressed Air Energy Storage (CAES), focusing on the technological development of \\ one of the key elements of such systems - the gas turbines. It presents the basic parameters and features of gas turbines, \\ as well as turbine classes with example models. Main tendencies in the structural and technological development are \\ discussed. Changes and trends on electric energy markets are becoming more and more dependent on sources with \\ flexible operating characteristics, therefore, the advantages of gas turbines and the reasons for their development are \\ listed as well.
}

Key words: energy storage, CAES, gas turbines, exhaust gas recirculation, gas turbines classes, modern gas turbine systems

\section{Turbiny gazowe - rozwój technologiczny i możliwość zastosowania w ukladach CAES}

W artykule przedstawiono krótka charakterystykę magazynowania energii w sprężonym powietrzu (CAES), skupiając się na przeglądzie osiagnięć technologicznych jednego z podstawowych elementów tych układów - turbin gazowych. Opisano podstawowe parametry i cechy turbin gazowych, a następnie klasy turbin z przykładowymi modelami. Przedstawiono główne tendencje w rozwoju konstrukcyjnym i technologicznym. Zmiany i trendy na rynkach energii elektrycznej coraz bardziej zależą od źródeł o elastycznej charakterystyce pracy, dlatego zestawiono również zalety i powody rozwoju turbin gazowych.

Słowa kluczowe: magazynowanie energii, CAES, turbiny gazowe, recyrkulacja spalin, klasy turbin gazowych, nowoczesne systemy turbin gazowych

\section{Introduction}

The supply of a sufficient amount of energy is one of the fundamental challenges that highly developed countries are currently facing most often. The conducted analyses show that the increase in power demand is close to $1 \%$ per year, while in recent years in Poland it amounted to $2 \%$ [1]. That is why the continuous development of power generating capacity, modernization of the existing high power units, support of distributed power generation and renewable energy sources are of crucial importance.

Energy derived from alternative energy sources, although inexhaustible and commonly available, is characterised by high variability in occurrence and is not correlated with the power demand of a system [2]. The development and capacity of energy storage has in recent years become one of the main objects of research for the purpose of ensuring stable operation of the electrical power system.

The demand for energy supplied to the NPS (National Power System) varies in time. It is related with short-term daily fluctuations in energy consumption and seasonal changes. When highly unpredictable sources are introduced into the system, electric energy generation is even more variable. Wind and solar power plants are both examples of such sources [1]. The rate of increase in wind power plants installed capacity made it necessary for many countries to search for new technical solutions providing for the stabilisation of the NPS. Energy storage in compressed air is one of the available solutions. The accumulated energy may be used in gas turbines in order to cover peak loads.

\section{Wprowadzenie}

Zapewnienie odpowiedniej ilości energii jest jednym z podstawowych wyzwań, jakie stoją przed gospodarkami szczególnie krajów wysoko rozwiniętych. Prowadzone analizy wskazują, że wzrost zapotrzebowania na energię elektryczną zbliżony jest do $1 \%$ rocznie, a w warunkach polskich w ciągu ostatnich lat wynosi $2 \%$ [1]. Z tego względu tak istotny jest ciągły rozwój mocy wytwórczych, modernizowanie istniejących bloków dużej mocy, wspieranie energetyki rozproszonej i odnawialnych źródeł energii.

Energia z alternatywnych źródeł energii, chociaż niewyczerpalna, ogólnie dostępna, charakteryzuje się dużą zmiennością występowania i nie jest skorelowana z zapotrzebowaniem na moc w systemie [2]. Rozwój i zdolność magazynowania energii jest jednym z głównych tematów badań w ostatnich latach. Konieczne jest to do zapewnienia stabilnej pracy systemu elektroenergetycznego.

Zapotrzebowanie na energię dostarczaną do KSE (Krajowy System Elektroenergetyczny) jest zmienne w czasie. Związane jest to $\mathrm{z}$ krótkotrwałymi wahaniami poboru energii w ciągu każdej doby oraz ze zmianami sezonowymi. Wprowadzenie do systemu źródeł cechujących się dużą niepewnością pracy powoduje nasilenie zmienności produkcji energii elektrycznej. Takimi źródłami są np. siłownie wiatrowe i solarne [1]. Skala wzrostu mocy zainstalowanej w elektrowniach wiatrowych spowodowała w wielu krajach konieczność poszukiwania nowych rozwiązań technicznych umożliwiających stabilizację KSE. Jednym z dostępnych rozwiązań jest magazynowanie energii w sprężonym powie- 
The first patents for gas turbines were issued in the 19th century. Solutions proposed by Stolze and Charles Curtis, however, were practically useless, as the amount of energy necessary to drive the compressor exceeded the energy generated on the turbine shaft. The first autonomously operating gas turbine was built in 1903 by Ægidius Elling (the compressor was consuming less power than the turbine itself was generating - it was possible to draw the excess power outside, in order to power other equipment).

The development of new materials and increasing competition on the market, as well as modular solutions and mass production brought a breakthrough for gas turbines in the $60 \mathrm{~s}$ [3]. The consequent development of cooling technology, the possibility of increasing the temperature of exhaust gas made wide application of those systems possible. Currently, those motors play a significant role in many areas of the economy besides electrical power engineering, mainly in aviation, land and sea transport. This results in a technological and structural diversification of gas turbines in the individual areas of their application.

\section{Energy storage in compressed air systems}

Old mine deposits, salt caverns, salt mine excavations, hard rock excavations, areas of emptied ground water layers are used for energy storage in the form of compressed air, where air is compressed to the level of approximately 70-80 bars [1].

In this type of power plants the generator is fuelled with liquid or gas fuel (a non renewable source). There is no inlet air compressor, however, that under normal conditions consumes approx. $60 \%$ of mechanical energy of a conventional generator. This enables a reduction of $\mathrm{CO}_{2}$ emissions (considering the generation of electric energy from wind) and an increase in efficiency as compared to a conventional gas power plant [2].

In the analysed type of power stations, low-cost energy is used that is available outside of the power system peak load hours - during the nights and on weekends. When wind conditions are favourable, the excess energy is used to supply the compressor that compresses air to large tanks (storages) [1]. The accumulated energy is used during peak hours or when wind conditions are unfavourable and power generation by power plants does not meet the planned amount (e.g. an amount commissioned by a consumer). In such cases the control system switches a fuelled gas turbine and feeds compressed air to the turbine.

Environmental friendliness of gas turbines, relatively low investment costs and high capacity reached by power units, simplicity and light weight of their structure, flexible movement, independence from water sources and possible automation led to the growing popularity of power stations with gas turbines, and their use is recommended for low capacity power plants, peak load power stations and in special circumstances. The use of this sort of solutions supports distributed generation.

Below is a potential technical solution to the collaboration between gas turbines and compressed air tanks. There are several systems involving energy storage in compressed trzu. Zgromadzona energia może być wykorzystywana w turbinach gazowych do pokrywania szczytowych obciążeń.

Pierwsze patenty na turbiny gazowe zostały wydane w XIX wieku. Jednak zaproponowane przez Stolze'a i Charlesa Curtisa rozwiązania były bezużyteczne z praktycznego punktu widzenia, gdyż ilość energii potrzebnej do napędu sprężarki przewyższała energię otrzymywaną na wale turbiny. Pierwszą pracującą samodzielnie turbinę gazową zbudował w 1903 roku Ægidius Elling (sprężarka pobierała mniejszą moc niż wytwarzała sama turbina nadmiar mocy można było odebrać na zewnątrz do napędu innych urządzeń).

Dzięki opracowaniu nowych materiałów, poprzez zastosowanie pakietowych rozwiązań i seryjnej produkcji, lata 60 . XX wieku stały się przełomowe dla turbin gazowych [3]. Wynikający z tego rozwój technologii chłodzenia, możliwość zwiększania temperatury spalania i temperatury gazów wylotowych pozwoliły na szerokie stosowanie tych układów. Obecnie, poza elektroenergetyką, silniki te mają istotne znaczenie w wielu obszarach gospodarki, głównie w lotnictwie, transporcie lądowym i morskim. Jest to przyczyną dużego zróżnicowania technologicznego i konstrukcyjnego turbin gazowych w poszczególnych obszarach zastosowań.

\section{Systemy magazynowania energii w sprężonym powietrzu}

Do magazynowania energii w postaci sprężonego powietrza wykorzystuje się stare złoża wyeksploatowanych kopalni, kawerny solne, wyrobiska kopalni soli, wyrobiska w strukturze twardych skał, przestrzenie po warstwach wodonośnych, w których powietrze jest sprężane do ciśnienia około 70-80 bar [1].

W tego typu elektrowniach generator prądotwórczy jest zasilany paliwem ciekłym lub gazowym (źródło nieodnawialne). Brak jest natomiast sprężarki powietrza wlotowego, która zużywa w normalnych warunkach ok. $60 \%$ energii mechanicznej konwencjonalnego generatora. Pozwala to na zmniejszenie emisji CO2 (uwzględniając produkcję energii elektrycznej z wiatru) i podniesienie sprawności w porównaniu z klasyczną elektrownią gazową [2].

W siłowniach rozważanego typu korzysta się z energii elektrycznej o niskim koszcie, dostępnej poza szczytami obciążenia systemu elektroenergetycznego, w dolinach energetycznych - w nocy, w weekendy. Dzieje się tak również w czasie korzystnych warunków wiatrowych - nadmiar energii wykorzystywany jest do zasilania kompresora, który spręża powietrze do wielkich zbiorników (magazynów) [1]. Zgromadzona energia wykorzystywana jest w godzinach obciążeń szczytowych, bądź w momentach, gdy występują niekorzystne warunki wiatrowe i produkcja energii elektrycznej przez elektrownie nie odpowiada założonej wielkości (np. zamówionej przez odbiorcę). W takich sytuacjach układ sterowania załącza turbinę gazową zasilaną paliwem oraz doprowadza sprężone powietrze do turbiny gazowej.

Ekologiczne zalety turbin gazowych, stosunkowo małe koszty inwestycyjne i wysokie moce osiągane przez bloki energetyczne, prostota i lekkość konstrukcji, elastyczność 
air. Figure 1 shows a system reaching the greatest efficiency, over $70 \%$. This is a system containing both a combustion chamber and a recuperator in the turbine section. There is no cooler downstream of the last stage of the compressor, because the generated heat is accumulated in the exhaust heat tank and may be used for heating compressed air released to the turbine stages (in systems without a combustion chamber) or to the combustion chamber, as shown in Fig. 1.

Such solutions are currently being designed and tested by those countries in which wind power engineering is most advanced. The main objectives of the tests include air tanks and heat exchangers and storages that recover exhaust heat generated during compression [1].

This article provides a structural and technological overview of one of the elements used in the discussed systems - gas turbines (the classification, list, diagrams will also include a compressor as an essential element of autonomously operating gas turbine units).

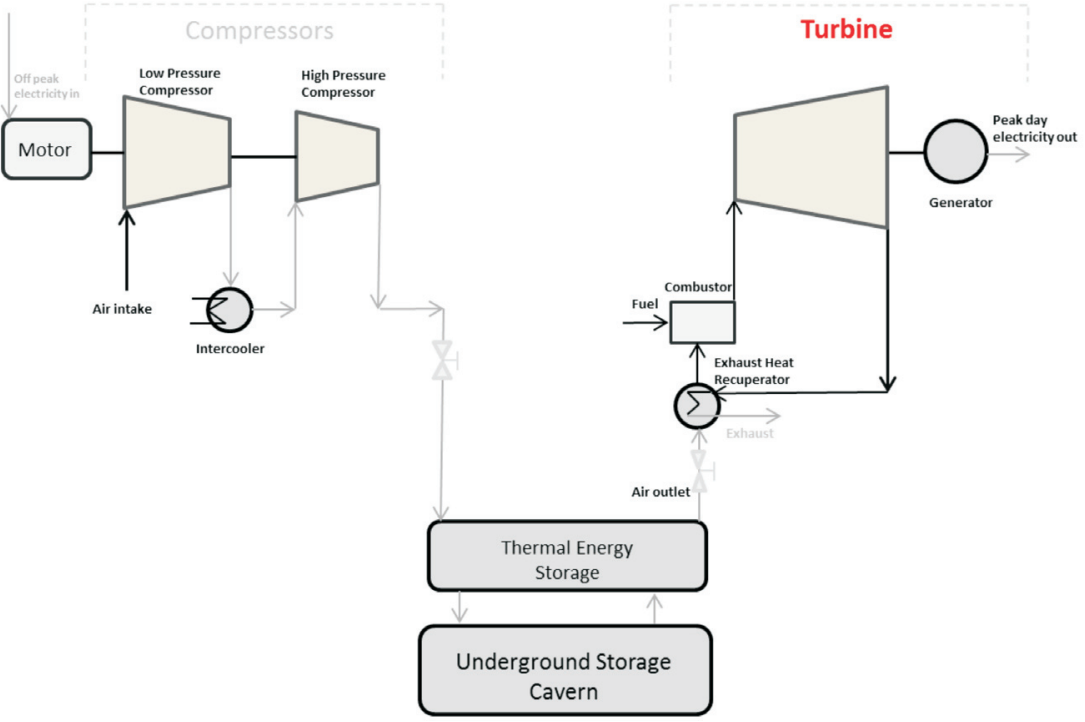

Fig. 1. A CAES system with exhaust heat storage, combustion chamber and recuperator [1] Rys. 1. Układ CAES z magazynem ciepła odpadowego, komora spalania i rekuperatorem [1]

\section{General classification of gas turbine sets}

Simply speaking, a gas turbine may be defined as a technologically advanced device in which the kinetic energy of the motion of the used medium or the potential energy of the medium under high pressure is converted into the turbine rotations [3]. Air is often (although not always) used as the medium. Then, the medium flow is generated as a result of fuel combustion, thus converting heat into mechanical energy. Gas turbine systems consume between three to four times more air than a sole fuel combustion process. The additional amount of air is necessary, mainly in order to ensure the sufficient cooling of high temperature flow parts of the turbine.

There are many criteria of gas turbines classification. With regards to the systems design, open and closed cycle systems may be distinguished [5]. In an open cycle system the medium is drawn from the atmosphere and after its ruchu, niezależność od źródeł wody i możliwość automatyzacji stanowią o rozpowszechnieniu siłowni z turbinami gazowymi, a stosowanie ich jest korzystne w elektrowniach małej mocy, elektrowniach szczytowych i w specjalnych okolicznościach. Stosowanie tego typu rozwiązań przyczynia się do wspierania energetyki rozproszonej.

Poniżej podano przykładowe rozwiązanie techniczne współpracy turbin gazowych i zbiorników ze sprężonym powietrzem. Istnieje kilka układów magazynowania energii w sprężonym powietrzu. Na rysunku 1 przedstawiono układ osiągający największą sprawność, wynoszącą ponad 70\%. Jest to układ zawierający komorę spalania oraz rekuperator w części turbinowej. Za ostatnim stopniem kompresora brak jest chłodnicy, ponieważ wytwarzane ciepło gromadzone jest w zbiorniku ciepła odpadowego, które może być wykorzystane do podgrzania sprężonego powietrza trafiającego na stopnie turbiny (w układach bez komory spalania), bądź tak jak na rys. 1 - do komory spalania. Tego typu rozwiązania są projektowane i testowane obecnie przez kraje, w których energetyka wiatrowa jest najbardziej rozwinięta. Głównym celem badań są zbiorniki powietrza oraz wymienniki i magazyny ciepła odzyskujące ciepło odpadowe sprężania [1].

Niniejszy artykuł stanowi przegląd konstrukcyjno-technologiczny dla jednego $\mathrm{z}$ elementów stosowanych $\mathrm{w}$ omówionych układach - turbin gazowych (w klasyfikacji, zestawieniu, schematach będzie przedstawiana również sprężarka jako element nieodzowny w samodzielne pracujących jednostkach turbin gazowych).

\section{Ogólna klasyfikacja zespołów turbin gazowych}

W najprostszym ujęciu turbinę gazową można określić jako urządzenie zaawansowane technologicznie, w którym energia kinetyczna ruchu stosowanego medium, bądź energia potencjalna medium znajdującego się pod dużym ciśnieniem, zostaje zmieniana na ruch obrotowy turbiny [3]. Medium tym często jest powietrze. Następnie w procesie spalania paliwa wytwarzany jest przepływ medium, dzięki któremu przekształcane ciepło transformowane jest w energię mechaniczną. W układach turbin gazowych zużywane jest od trzech do czterech razy więcej powietrza aniżeli wynikałoby to $z$ procesu spalania paliwa. Dodatkowe ilości powietrza potrzebne są między innymi do zapewnienia odpowiedniego chłodzenia wysokotemperaturowych części przepływowych w turbinie.

Istnieje wiele kryteriów klasyfikacji czy też podziału turbin gazowych. Z punktu widzenia struktury układów dzielimy je na otwarte i zamknięte [5]. Medium w układzie otwartym jest pobierane $\mathrm{z}$ otoczenia i po ekspansji $\mathrm{w}$ turbinie zostaje skierowane $\mathrm{z}$ powrotem do otoczenia (rys. 2a). Układy otwarte działają z izobarycznym spalaniem 
expansion in the turbine it is released back to the atmosphere (Fig. 2a). Open cycle systems operate with isobaric internal combustion. In a closed cycle system, the active medium circulates in the system (Fig. 2b).

The extent of Carnotisation (thermodynamic optimisation) of standard cycles (open cycle systems) and reference cycles (closed cycle systems) is another gas turbine systems classification. It includes simple systems - without regeneration, with one combustion chamber and a single-module compressing process, and complex systems - with regeneration, multiple combustion chambers, with the intermodular cooling of compressors.

Some of the used and designed gas turbines are based on a simple system, where the properties analysis is very important. Indexes that characterise a gas turbine include:

- effective power

$$
\mathrm{N}_{\mathrm{e}}=\mathrm{N}_{\mathrm{t}}-\mathrm{N}_{\mathrm{c}}-\Delta \mathrm{N}_{\mathrm{m}}
$$

where: $\mathrm{N}_{\mathrm{t}}$ - turbine internal power, $\mathrm{N}_{\mathrm{c}}-$ compressor internal power, $\Delta \mathrm{N}_{\mathrm{m}}$ - power loss resulting from dealing with mechanical resistance and the power of internal devices.

For CAES systems the equation is simplified with the compressor power, because at peak system loads compressed air is supplied from a compressed air accumulator. - efficiency

$$
\eta_{\mathrm{e}}=\frac{\mathrm{N}_{\mathrm{e}}}{\mathrm{N}_{\mathrm{f}}}=\frac{\mathrm{N}_{\mathrm{t}}-\mathrm{N}_{\mathrm{c}}-\Delta \mathrm{N}_{\mathrm{m}}}{\mathrm{m}_{\mathrm{f}} \cdot \mathrm{W}_{\mathrm{r}}}
$$

where: $N_{f}$ - power equivalent to the chemical energy of the supplied fuel in $\mathrm{MW}, \dot{\mathrm{m}}_{\mathrm{f}}-$ fuel mass flow in $\mathrm{kg} / \mathrm{s}, \mathrm{W}_{\mathrm{r}}$ - fuel calorific value in $\mathrm{MJ} / \mathrm{kg}$.

Similarly to the previous dependence, an increase in effective power in CAES systems leads to an increase in the efficiency of a gas turbine. The given values are strictly correlated with the technical and economical indexes of a turbine.

Currently, besides simple systems, combined systems are also used that combine a simple, open cycle gas turbine system with a steam power plant.

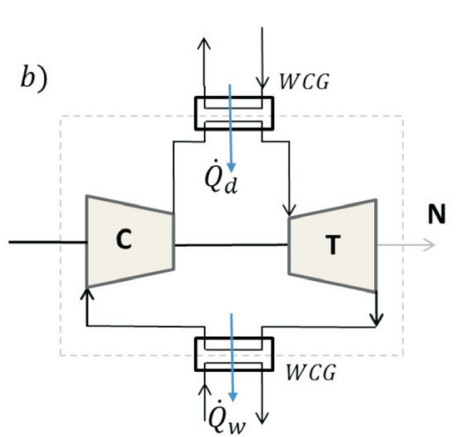

Fig. 2. Classification of gas turbines: a) open cycle system, b) closed cycle system; C compressor, $\mathrm{T}$ - turbine, $\mathrm{CC}$ - combustion chamber, $\mathrm{CHW}$ - precooler, WCG - upper heat exchanger, $\mathrm{N}-$ output, $\dot{\mathrm{m}}_{\mathrm{a}}-$ air stream, $\dot{\mathrm{m}}_{\mathrm{f}}-$ fuel stream, $\mathrm{Q}_{\mathrm{d}}-$ heat flux suplied to a closed cycle system, $\mathrm{Q}_{\mathrm{W}}$ - heat flux drawn from the precooler [7]

Rys. 2. Podział turbin gazowych: a) uktad otwarty, b) układ zamknięty; C-sprężarka, odła górnego, $N-$ moc, $\dot{m}_{a}-$ strumień powietrza, $\dot{m}_{f}-$ strumień paliwa, $\mathrm{Q}_{\mathrm{d}}-$ strumien ciepła doprowadzonego do uktadu zamkniętego, $\mathrm{Q}_{\mathrm{w}}-$ strumień ciepta wyprowadzony w chtodnicy wstępnej [7]

wewnętrznym. W układzie zamkniętym czynnik roboczy krąży w układzie (rys. 2b).

Zakres karnotyzacji obiegów standardowych (układy otwarte) i porównawczych (układy zamknięte) jest inną z klasyfikacji układów turbin gazowych. Klasyfikujemy układy proste - bez regeneracji z jedną komorą spalania i jednomodułowym procesem sprężania, oraz układy złożone - z regeneracją, z wieloma komorami spalania, z chłodzeniem międzymodułowym sprężarek.

Część eksploatowanych i budowanych turbin gazowych opiera się na układzie prostym; analiza właściwości jest bardzo istotna. Wskaźnikami charakteryzującymi turbinę gazową są: - moc efektywna

$$
\mathrm{N}_{\mathrm{e}}=\mathrm{N}_{\mathrm{t}}-\mathrm{N}_{\mathrm{c}}-\Delta \mathrm{N}_{\mathrm{m}}
$$

gdzie: $\mathrm{N}_{\mathrm{t}}$ - moc wewnętrzna turbiny, $\mathrm{N}_{\mathrm{c}}-$ moc wewnętrzna sprężarki, $\Delta \mathrm{N}_{\mathrm{m}}$ - straty mocy na pokonanie oporów mechanicznych oraz moc urządzeń własnych.

Dla układów CAES równanie to uproszczone jest o moc sprężarki, ponieważ sprężone powietrze w czasie maksymalnych obciążeń systemu dostarczane jest z zasobnika sprężonego powietrza.

Table 1. Development of high-power gas turbines designs [4, 8]

Tabela 2. Rozwój konstrukcji energetycznych turbin gazowych wielkiej mocy [4, 8]

\begin{tabular}{|l|c|c|}
\hline Parameter/Year/rok & 1967 & $\begin{array}{c}\text { Currently/obecnie, for J (J+) class turbines/ } \\
\text { dla turbin klasy J (in the future/w przyszłości) }\end{array}$ \\
\hline Temperature of exhaust gas at the turbine inlet/temperatura spalin na wlocie, ${ }^{\circ} \mathrm{C}$ & 900 & 1600 (1700) \\
\hline Compression ratio/spręż & 430.5 & Approx. 35 \\
\hline Outlet exhaust gas temperature/temperatura wylotowa spalin, ${ }^{\circ} \mathrm{C}$ & 650 \\
\hline Cooling of turbine blades/chłodzenie topatek turbiny & $\begin{array}{c}\text { Guide blades/ } \\
\text { kierowniczych (1) }\end{array}$ & $\begin{array}{c}\text { Guide blades/kierowniczych }(1,2,3) \text {, rotor } \\
\text { blades/wirnikowych (1,2,3) }\end{array}$ \\
\hline Range of peak power/zakres największych mocy, MW & $50-60$ & $320-470$ \\
\hline Efficiency in a simple cycle system/sprawność w obiegu prostym, \% & 29 & 41 (up to 45) \\
\hline Efficiency in a gas and steam system/sprawność w obiegu gazowo-parowym, $\%$ & 43 & $>61$ (62-65) \\
\hline
\end{tabular}


Power plants with gas turbines are one of the most rapidly developing types of power installations in the world (considering gas and steam systems). A technological revolution in gas turbines has taken place between the 60 s and the present day. The parameters of the changes are listed in Table 1.

Works on the development of gas turbine generations also include parallel works on improving the previous generations. Considering a gradual development of gas turbines, the manufacturers classify them into classes (Fig. 3). D class (and lower), F class, G class, H class, J class and $1700(\mathrm{~J}+)$ class turbines can be differentiated. It should be noted, however, that the same technology class designation used by different manufacturers does not necessarily mean the same solutions. For example, different manufacturers define the turbine inlet temperature differently (MHI defines it as the Turbine Inlet Temperature - temperature upstream of the first guide ring, while GE defines it as the Rotor Inlet Temperature - temperature upstream of the first rotor ring).

The general overview of individual turbosets crosssections in Fig. 3 shows that each new, improved solution is the result of continuous development of the technology (and not a result of leap changes and the introduction of completely new designs).

The increase in the efficiency of a turbine set is correlated with the Turbine Inlet Temperature increase and the improvement of the aerodynamics of the flow parts of the compressor and the expansion module, as well as the process of combustion and cooling of the blade system [7]. Various other operational procedures are applied in order to improve efficiency, e.g. the active medium is thoroughly filtered at the turbine inlet in order to remove contamination. It must be noted that practically all manufacturers of high power gas turbines currently offer a solution that provides a $40 \%$ efficiency in a simple cycle in the F class.

A continuous increase in temperatures in gas systems is possible through the development of material engineering,

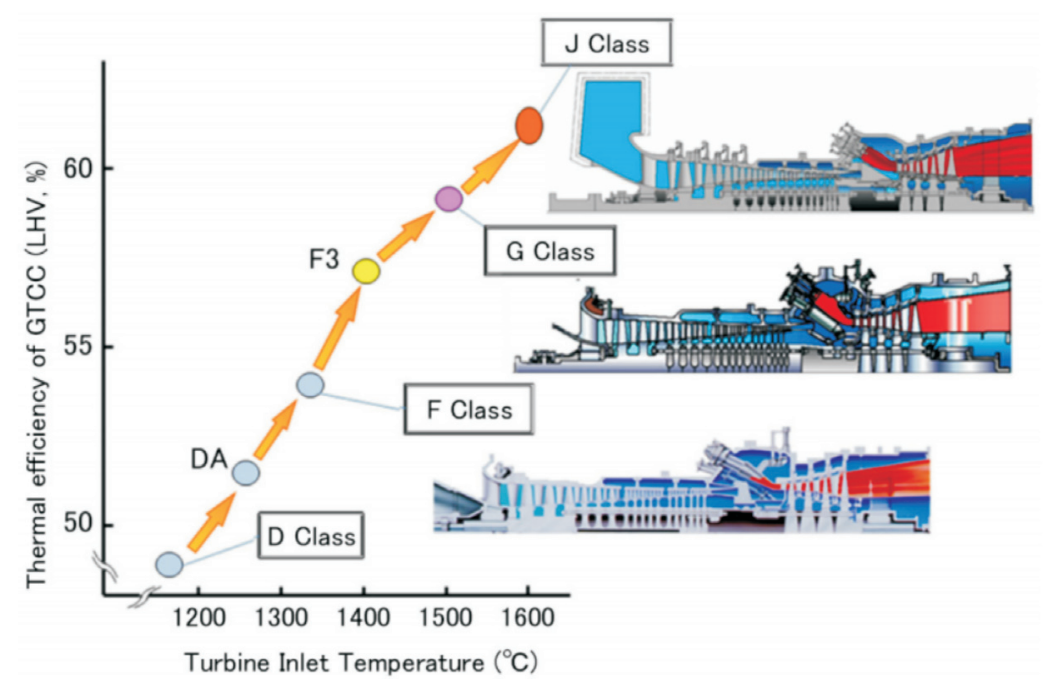

Fig. 3. Turbine classes acc. to Mitsubishi Heavy Industries and equivalent efficiencies with reference to application in steam and gas systems (MHI) [8]

Rys. 3. Klasy turbin wedtug Mitsubishi Heavy Industries i odpowiadajace im sprawności w odniesieniu do zastosowania w uktadach parowo-gazowych(MHI) [8]
- sprawność efektywna

$$
\eta_{\mathrm{e}}=\frac{\mathrm{N}_{\mathrm{e}}}{\mathrm{N}_{\mathrm{f}}}=\frac{\mathrm{N}_{\mathrm{t}}-\mathrm{N}_{\mathrm{c}}-\Delta \mathrm{N}_{\mathrm{m}}}{\mathrm{m}_{\mathrm{f}} \cdot \mathrm{W}_{\mathrm{r}}}
$$

gdzie: $\mathrm{N}_{\mathrm{f}}$ - moc odpowiadająca energii chemicznej doprowadzanego paliwa w MW, $\dot{\mathrm{m}}_{\mathrm{f}}$ - strumień masy paliwa $\mathrm{w} \mathrm{kg} / \mathrm{s}$, $\mathrm{W}_{\mathrm{r}}$ - wartość opałowa paliwa w $\mathrm{MJ} / \mathrm{kg}$.

Podobnie jak w poprzedniej zależności wraz ze wzrostem mocy efektywnej w układach CAES wzrasta sprawność efektywna turbiny gazowej. Podane wielkości mają ścisły związek ze wskaźnikami techniczno-ekonomicznymi turbiny.

Obecnie, poza układami prostymi, stosowane są układy kombinowane, które są połączeniem prostego układu otwartego turbiny gazowej i siłowni parowej.

Siłownie z turbinami gazowymi należą do najszybciej rozwijających się na świecie typów instalacji energetycznych (z uwzględnieniem układów gazowo-parowych). Od lat 60. XX wieku do czasów obecnych w turbinach gazowych nastąpiła rewolucja technologiczna. Parametry zmian przedstawia tabela 1 .

Praca nad rozwojem generacji turbin gazowych obejmuje również równoległe prace nad doskonaleniem poprzednich generacji. Uwzględniając stopniowy rozwój turbin gazowych, producenci posługują się klasami turbin (rys. 3). Wyróżnia się turbiny klasy D (oraz niższe), klasy F, klasy G, klasy H, klasy J i klasy 1700 (J+). Należy jednak pamiętać, iż oznaczenie klasy technologii u poszczególnych wytwórców nie musi oznaczać rozwiązań tej samej klasy. Przykładem może być fakt, że poszczególni producenci temperaturę dolotową do turbiny definiują w różny sposób (MHI definiuje ją jaki temperaturę przed pierwszym wieńcem kierowniczym (Turbine Inlet Temperature), zaś GE jako temperaturę przed pierwszym wieńcem wirnika (Rotor Inlet Temperature).

Widoczny na rysunku 3 ogólny zarys przekrojów poszczególnych turbozespołów wskazuje, że kolejne, doskonalsze rozwiązania są efektem ciagłego rozwoju technologii (nie jest efektem skokowych zmian i budowy zupełnie nowych konstrukcji).

Wzrost sprawności zespołu turbiny skorelowany jest ze wzrostem temperatury (Turbine Inlet Temperature) w przekroju wlotu do turbiny oraz doskonalenia aerodynamiki części przepływowych sprężarki i modułu ekspansyjnego, a także procesu spalania i chłodzenia układu łopatkowego [7]. W celu poprawienia wydajności stosuje się również wiele dodatkowych zabiegów eksploatacyjnych, np. medium robocze na wlocie do turbiny jest dokładnie filtrowane w celu eliminacji zanieczyszczeń. Należy zwrócić również uwagę na to, iż prawie wszyscy wytwórcy turbin gazowych dużej mocy oferują obecnie rozwiązanie umożliwiające uzyskanie w klasie F sprawności w obiegu prostym na poziomie $40 \%$. 


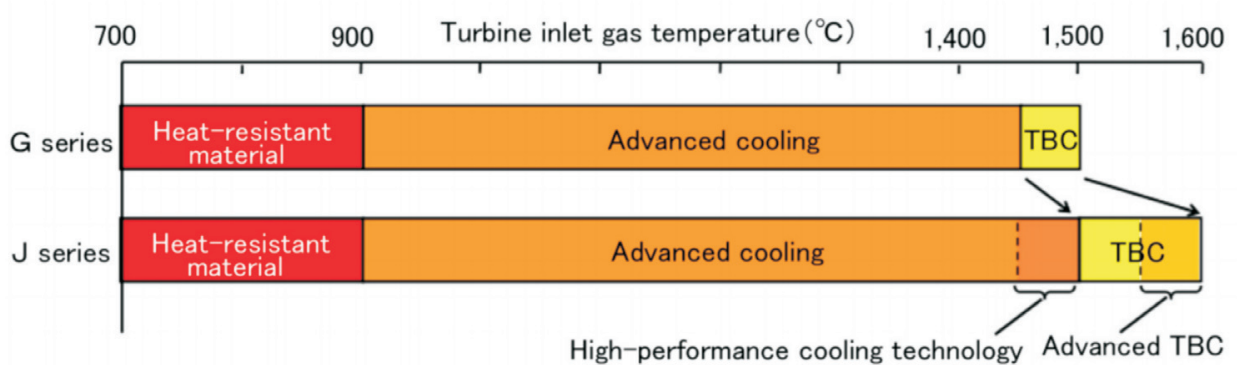

Fig. 4. Increase in temperatures upstream of the turbine with the development of the cooling technology [10] Rys. 4. Wzrost temperatury przed turbina wraz z rozwojem technologii chłodzenia [10]
Osiągniecie ciągłego wzrostu temperatur występujących w układach gazowych możliwe jest dzięki rozwojowi inżynierii materiałowej, stosowaniu powłok ceramicznych mających mniejszą przewodność cieplną i niższy stopień utleniania oraz doskonaleniu procesu chłodzenia (rysunek 4 przedstawia zmiany na

the use of ceramic coatings characterised by lower thermal conductivity and a lower oxidation number, as well as the improvement of the cooling process (Figure 3 shows the changes on the example of classes $\mathrm{G}$ and $\mathrm{J}$ through the use of advanced TBC ceramic protective coatings for Mitsubishi turbines).

In recent years key manufacturers have released highefficiency and high-power gas turbines. One of them is a gas turbine by GE, model 9HA.2 (Fig. 5), reaching the output power of $510 \mathrm{MW}$ and an efficiency of $61 \%$ (for combined systems). The Turbine Inlet Temperature reaches $1426^{\circ} \mathrm{C}$. It is an $\mathrm{H}$ class turbine.

Mitsubishi M501J that is to be released in 2016 is an example of a J class turbine. For sets operating at the frequency of $50 \mathrm{~Hz}$, the turbine output reaches $460 \mathrm{MW}$. In a combined gas and steam system, with the use of 1 gas turbine and 1 steam turbine, it is possible to reach the output of $670 \mathrm{MW}$ [10]. The Turbine Inlet Temperature reaches $1600{ }^{\circ} \mathrm{C}$, while the emission of $\mathrm{NO}_{\mathrm{x}}-25 \mathrm{ppm}$ (it was made possible by eliminating temperature peaks of the flame through the improvement of air and fuel supply to the burners).

The system involves a 15-stage transonic compressor (transonic flow - flow at speeds near the speed of sound) characterised by lower wave losses at the first rings, as well as lower profile losses at intermediate and final stages [10]. Blade rings, as well as the three guide rings of the turbine

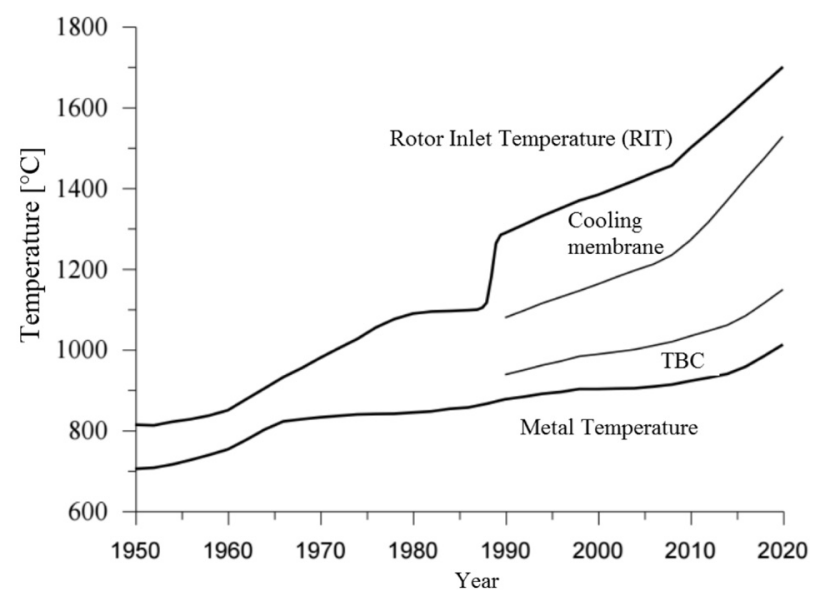

Fig. 6. Increase in the temperature of exhaust gas and blades material in gas turbines [4]

Rys. 6. Wzrost temperatury spalin oraz materiału topatek $w$ turbinach gazowych [4] przykładzie klasy G i J przez zastosowanie zaawansowanych ceramicznych powłok ochronnych TBC, dla turbin firmy Mitsubishi).

W ostatnich latach główni producenci wprowadzili na rynek turbiny gazowe o wysokich sprawnościach i mocach.

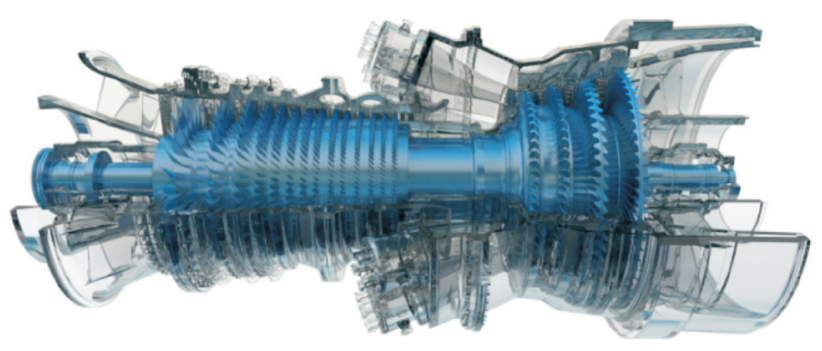

Fig. 5. GE 9HA.2 gas turbine [11]

Rys. 5. Turbina gazowa GE 9HA.2 [11]

Jedną z nich jest turbina gazowa firmy GE model 9HA.2 (rys. 5), osiągająca moc 510 MW oraz sprawność 61\% (dla układów kombinowanych). Temperatura na wlocie do turbiny wynosi $1426^{\circ} \mathrm{C}$. Jest to turbina klasy $\mathrm{H}$.

Przykładem turbiny klasy J może być planowana do wprowadzenia w 2016 roku turbina firmy Mitsubishi M501J. Dla zespołów pracujących z częstotliwością $50 \mathrm{~Hz}$ moc turbiny wynosi $460 \mathrm{MW}$. W układzie kombinowanym, gazowo-parowym przy zastosowaniu 1TG 1 TP możliwe jest otrzymanie mocy $670 \mathrm{MW}$ [10]. Temperatura wlotowa do ekspandera wynosi $1600^{\circ} \mathrm{C}$, a emisja $\mathrm{NO}_{\mathrm{x}} 25$ ppm (było to możliwe przez likwidację pików temperaturowych płomienia dzięki udoskonaleniu doprowadzenia powietrza i paliwa do palników).

W układzie zastosowano 15-stopniową sprężarkę transoniczną (przepływ transoniczny - przepływ okołodźwiękowy), która charakteryzuje się mniejszymi stratami falowymi w pierwszych wieńcach, a także mniejszymi stratami profilowymi na stopniach pośrednich i ostatnich [10]. Wieńce łopatkowe oraz trzy wieńce kierownicze turbiny chłodzone są powietrzem odbieranym ze sprężarki po schłodzeniu w chłodnicy zewnętrznej. Intensyfikacja wymiany cieplnej przez wielonawrotowe chłodzenie i rozwiązania otworowego chłodzenia błonowego pozwoliły opanować wzrost temperatury wlotowej. 
are cooled with air drawn from the compressor following cooling in an external cooler. The intensification of heat exchange through multiple-reverse cooling and the film hole cooling method made it possible to control the increase in the inlet temperature.

Figure 6 shows tendencies for the increase in the maximum temperature of the active medium in gas turbine systems. With the introduction of air cooling, an increase in the inlet exhaust gas temperature became possible when combined with the use of the materials technology. This translates into a cost increase that, on the other hand, is compensated for with higher efficiency and capacity.

In the nearest future it is planned to release a design of turbines that can operate at temperatures exceeding $1700^{\circ} \mathrm{C}$ and with efficiency reaching $65 \%$ (for combined systems).

\section{Regulatory properties of gas turbines}

In recent years considerable emphasis has been placed on the power engineering strategy in energy storage and distributed generation, as well as adjustable sources. Transmission operators have at their disposal a series of centrally dispatched power plants, i.e. plants that may be switched on or off, as well as change their load to match the demand. Gas power plants are characterised by relatively high operational flexibility and short start-up times, which is why they are the ideal peak load sources.

In stationary gas turbine systems with a single-shaft arrangement, the compressor pumps air into the combustion chamber and is driven by a turbine mounted on a common shaft that is supplied with exhaust gas from the combustion chamber. In power engineering solutions, the constant rotational speed of the rotor proves to be a significant obstacle. When analysing the characteristics of gas turbines it becomes clear that partial loading is accompanied by a reduction in the system parameters.

That is why the flattening of the characteristic curves, the acceleration of start-ups translating into the maximisation of the turbines load is the goal. The use of gas turbines in CAES systems supporting the operation of wind turbines and constituting storage used at peak loads eliminates the issue of low efficiency when operating at partial loads, because operation on an interventional basis enables the utilisation of maximum outputs installed in a system.

$\mathrm{n}$ important element of gas turbines that is currently being developed by the manufacturers are the compressors, in which additional stages are being introduced with regulated guide blades, and in which efficiency is increased through the spatial shaping of the compressor blades. The notion of spatial blading includes some structural modifications that involve simple or complex tilting and rolling of blades, customised selection and optimisation of a profile along the height of a blade, as well as the shaping of the external constraints of a channel. Those actions also make increased regulation of systems possible, thus increasing their efficiency and operational flexibility, as well as shortening start-up times.

At the beginning of 2015 the installed capacity in gas turbines in the National Power System amounted to approximately $1000 \mathrm{MW}$ out of approximately $31000 \mathrm{MW}$
Na rysunku 6 przedstawiono tendencje wzrostu maksymalnej temperatury czynnika roboczego w układach turbin gazowych. Od wprowadzenia chłodzenia powietrznego podwyższanie temperatury dolotowej spalin stało się możliwe w połączeniu z wykorzystaniem technologii materiałowej. Powoduje to wzrost kosztów, które jednak kompensuje większa sprawność i wzrost mocy.

W najbliższych latach planowane jest przedstawienie konstrukcji turbin mogących pracować z temperaturami powyżej $1700{ }^{\circ} \mathrm{C}$ i sprawnością sięgającą $65 \%$ (dla układów kombinowanych).

\section{Wlaściwości regulacyjne turbin gazowych}

W ostatnim latach w strategii elektroenergetycznej bardzo duży nacisk położono na magazynowanie energii i generację rozproszoną oraz źródła sterowalne. Operatorzy Przesyłowi mają do dyspozycji wiele elektrowni centralnie dysponowanych, czyli takich, które mogą być włączone lub wyłączone, a także zmieniać swoje obciążenie w zależności od zapotrzebowania. Elektrownie gazowe charakteryzują się stosunkowo dużą elastycznością pracy i krótkimi czasami rozruchów, dlatego idealnie wpisują się w charakter źródeł szczytowych.

W układach stacjonarnych turbin gazowych w układzie jednowałowym sprężarka tłoczy powietrze do komory spalania i napędzana jest przez turbinę osadzoną na wspólnym wale, która z kolei zasilana jest spalinami z komory spalania. W rozwiązaniach dla energetyki dużym ograniczeniem jest stała prędkość obrotowa wirnika. Analizując charakterystyki turbin gazowych, można zauważyć, iż częściowemu obciążeniu towarzyszy obniżenie parametrów układu. $\mathrm{Z}$ tego względu dąży się do wypłaszczania charakterystyk, przyspieszania rozruchów przekładających się na maksymalizację obciążenia turbin. Stosowanie turbin gazowych w systemach CAES wspierających pracę turbin wiatrowych i będących magazynem wykorzystywanym w szczytowych obciążeniach, eliminuje wadę, jaką jest niska sprawność przy pracy na niepełnym obciążeniu, ponieważ praca interwencyjna pozwoli osiągnąć maksymalne moce zainstalowane w układzie.

Istotnym elementem turbin gazowych rozwijanym przez producentów są sprężarki, w których wprowadza się większą liczbę stopni z regulowanymi łopatkami kierowniczymi, podnosi się sprawność przez przestrzenne kształtowanie łopatek sprężarki. Pojęcie ołopatkowania przestrzennego obejmuje pewną ilość modyfikacji konstrukcyjnych, które polegają na prostym lub złożonym pochylaniu i zwijaniu łopatek, indywidualnym doborze i optymalizacji profilu wzdłuż wysokości łopatki oraz kształtowaniu ograniczeń zewnętrznych kanału. Działania te pozwalają również na większą regulację układów, podnosząc ich sprawność, zwiększając elastyczność pracy i szybkość rozruchu.

Na początku 2015 roku w KSE moc zainstalowana w turbinach gazowych wynosiła około $1000 \mathrm{MW}$, z około 31000 MW łącznie zainstalowanych źródeł wytwórczych w energetyce zawodowej. 
of all installed generation sources in commercial power engineering.

\section{Conclusions}

The current technological advancement, technical, economical, and environmental conditions and the potential use of energy storage by gas turbines translate into an increase in the share of gas turbines in European power engineering. Those systems may play the role of peak load (balancing) sources in the system. Quick start-up, flexibility, relatively short construction time, low maintenance and service costs, low emission of noxious substances - these are just some of the advantages of gas turbines.

As part of a search for new solutions, closed cycle systems with carbon dioxide as a medium are being analysed, aiming for a continuous increase in efficiency, units capacity and emissions minimisation.

The continued development of unstable renewable energy sources will result in an increase in the competitiveness of gas turbines and CAES systems when compared to other peak load units.

A significant advantage to combined wind and CAES power plants is the increase in local energy security, because it is possible to start up a combined system without external supply and reach the desired capacity in a short period of time (the advantage is the possible autonomous operation of a gas turbine during expansion).

The start up time of CAES systems to their full capacity is two or even three times shorter than an average start up time of a unit with a gas turbine, and it takes approximately 10 minutes.

\section{Podsumowanie}

Osiągnięty poziom technologiczny, uwarunkowania techniczne, ekonomiczne, ekologiczne oraz możliwość współpracowania turbin gazowych z magazynami energii wpływają na wzrost udziału turbin gazowych w energetyce europejskiej. Układy te mogą spełniać rolę źródeł szczytowych (bilansujących) w systemie: szybki rozruch, elastyczność, stosunkowo krótki czas budowy, niskie koszty utrzymania i obsługi, mała emisja szkodliwych substancjito tylko niektóre z zalet turbin gazowych.

W ramach poszukiwań nowych rozwiązań analizuje się zamknięte układy z dwutlenkiem węgla jako czynnikiem roboczym, dążąc jednocześnie do dalszego wzrostu sprawności, mocy jednostek i zmniejszania emisji.

Dalszy rozwój niestabilnych odnawialnych źródeł energii będzie przyczyniał się do wzrostu konkurencyjności turbin gazowych i układów typu CAES w stosunku do innych jednostek szczytowych.

Bardzo istotną zaletą hybrydowych elektrowni w układzie farmy wiatrowe-CAES jest wzrost lokalnego bezpieczeństwa energetycznego. Istnieje bowiem możliwość uruchomienia układu hybrydowego bez zasilania z zewnątrz i uzyskania żądanej mocy w krótkim czasie (zaletą jest możliwość samodzielnej pracy turbiny gazowej podczas procesu rozprężania).

Rozruch układów CAES do pełnej mocy jest od dwóch do trzech razy krótszy od przeciętnego czasu rozruchu bloku z turbiną gazową i wynosi około 10 minut.

\section{Bibliography/Literatura}

[1] Jakowski D., Dzida M. Energy storage in compressed air solution supporting renewable energy source, Journal of Polish CIMAC., vol. 9., nr 1 (2014), s. 35-45.

[2] Badyda K., Milewski J., Elektrownie CAES - możliwość akumulacji energii oraz współpracy ze źródłami odnawialnymi, Miesięcznik Instal -Teoria i praktyka w instalacjach - Warszawa 2010.

[3] Wędzik A. Układy kombinowane produkcji energii elektrycznej, Energetyka, maj 2006.

[4] Badyda K. Perspektywy rozwoju technologii turbin gazowych oraz bloków gazowo-parowych, Rynek Energii, sierpień 2014.

[5] Kleszcz T. Analiza porównawcza obiegów cieplnych elektrowni gazowo-parowych, Praca dyplomowa, Politechnika Łódźka.

[6] Perycz S. Turbiny parowe i gazowe. Polska Akademia Nauk, Instytut Maszyn Przepływowych, 1992.

Damian Jakowski, MEng. - assistant in the Faculty of Ocean and Ship Technology at Gdańsk University of Technology.

Mgr inż. Damian Jakowski - asystent na Wydziale Oceanotechniki i Okrętownictwa Politechniki Gdańskiej.

e-mail: damian.jakowski@pg.gda.pl

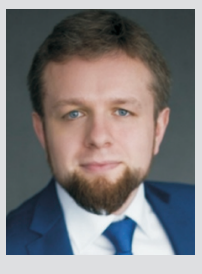

[7] Chmielniak T. Główne tendencje w procesie rozwoju turbiny gazowej, Rynek Energii nr 3(112), 2014.

[8] Toshishige A., Junichiro M., Eisaku I. Development of the High Efficiency and Flexible Gas Turbine M701F5 by Applying "J" Class Gas Turbine Technologies, Mitsubishi Heavy Industries Technical Review Vol. 51 No. 1 (March 2014).

[9] Robak S., Rasolomampionona D., Szymankiewicz Ł. Praca elektrowni gazowych w systemie elektroenergetycznym, Rynek Energii nr 3/2013.

[10] Masanori Y., Junichiro M., Keizo T., Eisaku I., Satoshi H. Development of $1600{ }^{\circ} \mathrm{C}$-Class High-efficiency Gas Turbine for Power Generation Applying J-Type Technology, Mitsubishi Heavy Industries Technical Review Vol. 50 No. 3 (september 2013).

[11] GE Power\&Water, 9HA.01/02 Gas turbine: The World's Largest and Most Efficient Heavy Duty Gas Turbine.

Prof. Marek Dzida, DSc., DEng. - Head of the Department in the Faculty of Ocean and Ship Technology at Gdańsk University of Technology.

Dr hab. inż. Marek Dzida, prof. PG - Kierownik katedry na Wydziale Oceanotechniki i Okrętownictwa Politechniki Gdańskiej.

e-mail: dzida@pg.gda.pl 